\title{
PENAMBAHAN IKAN LELE (CLARIAS GARIEPINUS) DAN ISOLATED SOY PROTEIN TERHADAP DAYA TERIMA DAN KADAR PROTEIN CILOK
}

\author{
Sri Lestari ${ }^{1}$, Annis Catur Adi ${ }^{2}$ \\ ${ }^{1}$ Prodi S1 Ilmu Kesehatan Masyarakat, Minat Gizi Fakultas Kesehatan Masyarakat Universitas Airlangga \\ ${ }^{2}$ Departemen Gizi Kesehatan, Fakultas Kesehatan Masyarakat, Universitas Airlangga, Surabaya \\ Email: srilestari.rii@gmail.com
}

\begin{abstract}
ABSTRAK
Beberapa penelitian menunjukkan kecukupan protein dari jajanan untuk anak SD masih kurang. Ketersediaan jajanan di sekolah memegang peranan penting untuk melengkapi kebutuhan protein siswa SD. Tujuan penelitian adalah untuk menganalisis pengaruh penambahan ikan lele (Clarias gariepinus) dan Isolated Soy Protein (ISP) terhadap daya terima dan kadar protein cilok (jajanan). Tahap pengembangan formulasi menggunakan penelitian eksperimental murni dengan Rancangan Acak Lengkap (RAL). Pengulangan dilakukan sebanyak 4 kali pada lima perlakuan (satu kontrol dan empat modifikasi yaitu F1diberi penambahan ISP, F2 diberi penambahan ikan lele, F3 diberi penambahan tepung ikan lele, dan F4 diberi penambahan ikan lele dan ISP). Penilaian daya terima menggunakan uji hedonik. Variabel penelitian adalah daya terima (warna, aroma, tekstur, dan rasa) dan kadar protein. Uji daya terima dilakukan kepada panelis berjumlah 71 siswa SD. Perbedaan daya terima (warna, aroma, tekstur, dan rasa) pada 5 formula diuji menggunakan Cochran's $Q$; uji terhadap formula yang berbeda menggunakan uji Mc Nemar. Hasil uji hedonik menunjukkan panelis lebih menyukai F0. Kandungan protein cilok berdasarkan perhitungan DKBM paling tinggi yaitu pada formula F4 dan hasil uji laboratorium kandungan protein sebesar 9,4g/ 100g lebih tinggi dari angka kecukupan yang dianjurkan. Hasil uji Cochran's $Q$ menunjukkan perbedaan daya terima pada karakteristik warna $(\mathrm{p}=0,002)$ dan $\mathrm{rasa}(\mathrm{p}=0,047)$ cilok. Uji Mc Nemar menunjukkan formula yang berbeda pada warna adalah F0 dengan F3, F1 dengan F3, dan F2 dengan F3, pada kategori rasa formula yang berbeda pada F0 dengan F3. Kesimpulannya yaitu bahwa F4 memiliki kadar protein paling tinggi namun daya terima masih rendah sehingga disarankan untuk memodifikasi F4 agar dapat diterima tetapi tidak mengubah kandungan proteinnya.
\end{abstract}

Kata kunci: cilok, daya terima, protein

\section{ABSTRACT}

Some research found that protein adequacy from snack for elementary school children are still lacked. Snacks availability at schools have an important role to fulfill protein requirement for students. The purpose of this research was to analyze the effect of catfish (Clarias gariepinus) and Isolated Soy Protein (ISP) addition on acceptance level and protein content of cilok (snack). Research methods used for formula development was experimental research with completely randomized design. Repetition was performed four times on five treatments (one control and four modifications, those are F1 was added ISP, F2 was added catfish, F3 was added catfish flour, and F4 was added catfish and ISP). Assessment of acceptance used hedonic test. Variable in this research was acceptance level (color, aroma, texture, and flavor) and protein content. Hedonic test was performed to 71 students. The difference of acceptance (color, aroma, texture, and flavor) between 5 formulas was tested used Cochran's $Q$; the difference within formula then analyzed by Mc Nemar test. Hedonic test result showed that panelists preferred F0. F4 had highest protein level based on DKBM and laboratory analysis found protein level $(9.4 \mathrm{~g} / 100 \mathrm{~g})$ higher than recommended value. Cochran's $Q$ test showed significant difference acceptance on color $(p=0.002)$ and taste $(p=0.047)$. Mc Nemar test showed the difference within formula on the color was F0 with F3, F1 with F3, and F2 with F3, while difference flavor formula found in FO with F3. This research concluded that F4 had the highest protein level but the acceptance was still low, it is recommended to modify F4 so that it become more acceptable but did not change the protein content.

Keywords: cilok, acceptance, protein 


\section{PENDAHULUAN}

Usia sekolah merupakan fase kritis di dalam daur kehidupan, terutama terhadap pertumbuhan dan perkembangan anak. Pada masa ini, anak mulai mengenal lingkungan sekitar sehingga faktor lingkungan mulai berpengaruh terhadap keadaan gizi dan kesehatan anak usia sekolah (Almatsier, 2011). Periode usia sekolah merupakan penentu baik buruknya kualitas manusia saat dewasa. Anak usia sekolah membutuhkan zat gizi protein yang harus dipenuhi dalam membantu proses pertumbuhan dan perkembangan fisik menuju dewasa. Anak usia sekolah pada umumnya lebih banyak menghabiskan waktunya di sekolah dari pada di rumah sehingga kesempatan untuk mengonsumsi jajanan juga semakin besar.

Penelitian yang dilakukan oleh Hapsari (2013) di SD Negeri Plalan 1 Surakarta memberikan gambaran bahwa kontribusi protein jajanan sebesar 9,2\% terhadap total konsumsi makanan sehari untuk anak SD. Pola makan sehat dan seimbang terdiri dari $15 \%$ protein dari total energi yang dibutuhkan (Irianto, 2007).

Makanan jajanan merupakan faktor yang penting bagi pertumbuhan dan perkembangan anak. Jajanan menyumbangkan energi dan zat gizi yang diperlukan untuk pertumbuhan anak sehingga jajanan yang berkualitas baik akan mempengaruhi kualitas makanan anak (Murphy, et al.,2007). Anak sekolah rata-rata memilih makanan jajanan dengan kandungan energi dan protein yang rendah sehingga sumbangan energi dan protein dari makanan jajanan terhadap total konsumsi sehari masih rendah (Hapsari, 2013).

Banyak faktor yang mendasari pemilihan jajanan dari anak SD, kondisi sosial ekonomi keluarga siswa yang mempengaruhi pemberian uang saku dan ketersediaan jajanan yang ada di sekolah. Hasil studi kasus di SDN Lawanggintung 01 Kota Bogor menegaskan bahwa terdapat hubungan antara alokasi uang saku dengan kebiasaan jajan anak SD (Syafitri, dkk., 2009). Hasil penelitian Aprillia (2011) pada salah satu SD di Semarang menunjukkan bahwa besar uang jajan di SD tersebut berkisar antara Rp 500 hingga $\mathrm{Rp}$ 5.000 ketika di sekolah $(95,9 \%)$.
Penelitian yang dilakukan oleh Hidayati (2005) tentang makanan jajanan di SDN 1 Pamijen Sukaraja menunjukkan bahwa sebagian besar makanan jajanan yang dijual belum memenuhi nilai gizi yang diharapkan. Makanan semi basah seperti cilok, mendoan, bakwan, timus goreng, dan sosis goreng, berat per porsi hanya 5 hingga 30 gram, dengan nilai protein antara 0 hingga 3,2 gram. Angka tersebut masih jauh dari nilai gizi yang diharapkan dapat disumbangkan dari makanan jajanan.

Salah satu jajanan yang disukai anak sekolah adalah cilok Nilai gizi cilok perlu mendapatkan perhatian khusus terkait masih rendahnya kandungan protein sehingga belum memenuhi kebutuhan anak sekolah. Cilok yang beredar di kalangan anak sekolah hanya terbuat dari tepung kanji dan tepung terigu dimana kedua bahan tersebut kurang mengandung protein (Suprapti, 2005). Protein dibutuhkan anak sekolah karena memiliki fungsi bagi tubuh yaitu sebagai sumber zat pembangun dan pemeliharaan jaringan tubuh, mempertahankan tubuh dari mikroba dan toksik, serta pengatur metabolisme tubuh dan hormon (Andriani dan Wirjatmadi, 2012).

Berdasarkan studi yang dilakukan di Mesir, Kenya dan Meksiko ditemukan hubungan yang positif antara asupan makanan sumber hewani dengan pertumbuhan, perkembangan kognitif dan aktivitas fisik pada anak usia sekolah (Neumann, et al., 2003). Ikan lele (Clarias gariepinus) merupakan salah satu sumber protein hewani yang sudah dikenal masyarakat, selain bernilai gizi protein cukup tinggi, serapan pasar terhadap komoditas ini juga cukup tinggi dan harganya terjangkau.

Jajanan cilok yang ditambahkan ikan lele (Clarias gariepinus) dapat lebih diperkaya kandungan proteinnya dengan penambahan Isolated Soy Protein (ISP). Isolated Soy Protein (ISP) merupakan sumber protein nabati yang berasal dari kedelai. Kedelai merupakan kacangkacangan yang mengandung delapan jenis asam amino esensial. Kedelai juga merupakan sumber yang baik dari serat, zat besi, kalsium, seng, dan vitamin B (Montgomery, 2003). Isolated Soy 
Protein (ISP) berbentuk tepung atau bubuk dengan kandungan protein mulai dari 90\%. Protein ini juga bebas lemak dan karbohidrat (Mindell, 2008).

Keragaman kandungan ikan lele (Clarias gariepinus) dan Isolated Soy Protein (ISP) dapat digunakan sebagai kombinasi bahan untuk membuat alternatif jajanan anak sekolah yang aman dan bernilai gizi yaitu cilok sehat dengan tambahan ikan lele (Clarias gariepinus) dan Isolated Soy Protein. Cilok sehat merupakan modifikasi cilok yang diharapkan dapat meningkatkan daya terima dan kadar protein cilok sehingga memenuhi kebutuhan protein anak SD dalam bentuk jajanan.

Penelitian ini bertujuan untuk menganalisis pengaruh penambahan ikan lele (Clarias gariepinus) dan Isolated Soy Protein terhadap daya terima dan kadar protein cilok

\section{METODE}

Penelitian ini terdiri dari beberapa tahap yaitu tahap pengembangan formulasi dan tahap penelitian untuk pengujian daya terima dan kadar protein cilok. Tahap pengembangan formulasi merupakan jenis penelitian eksperimental murni. Rancangan percobaan yang digunakan adalah rancangan acak lengkap (RAL) dengan 4 kali pengulangan pada 5 jenis perlakuan ( 1 formula kontrol dan 4 formula modifikasi yang terdiri dari F1 cilok dengan penambahan ikan lele (Clarias gariepinus), F2 cilok dengan penambahan Isolated Soy Protein (ISP), F3 cilok dengan penambahan tepung ikan lele (Clarias gariepinus), dan F4 cilok dengan penambahan ikan lele (Clarias gariepinus) dan Isolated Soy Protein (ISP)).

Kebutuhan protein untuk anak sekolah usia 7 hingga 12 tahun berdasarkan Angka Kecukupan Gizi (AKG) tahun 2013 sebesar 49 gram hingga 56 gram untuk anak laki-laki, dan 49 gram hingga 60 gram untuk anak perempuan. Penambahan daging ikan lele (Clarias gariepinus), Isolated Soy Protein (ISP) dan tepung ikan lele (Clarias gariepinus) pada cilok diharapkan dapat menyumbang protein sebesar 10\% hingga 15\% dari total kebutuhan protein dalam sehari. Maka, total kebutuhan protein yang diharapkan dari jajanan cilok ini berkisar antara 4,9 hingga 8,4 gram untuk anak laki-laki, dan 4,9 hingga 9,0 gram untuk anak perempuan. Perhitungan formulasi cilok didasari pada perhitungan kecukupan protein cilok pada anak usia sekolah. Penelitian ini terdiri dari formula F0, F1, F2, F3, dan F4 dengan persentase formulasi cilok pada Tabel 1.

Bahan yang digunakan pada penelitian ini adalah tepung kanji dan tepung terigu sebagai bahan dasar pembuatan cilok, daging ikan lele (Clarias gariepinus), Isolated Soy Protein (ISP), tepung ikan lele (Clarias gariepinus) sebagai bahan tambahan cilok modifikasi. Semua bahan tersebut memiliki lingkungan dan kondisi yang bersifat homogen. Panelis dalam penelitian ini terdiri dari panelis tidak terlatih berjumlah 71 siswa SD yang diambil dengan cara total sampling. Instrumen yang digunakan pada penelitian ini adalah angket uji hedonik, alat tulis, kalkulator, DKBM, tabel AKG, peralatan dan perlengkapan untuk memasak cilok.

Uji daya terima (meliputi warna, aroma, tekstur, dan rasa) pada cilok dinilai menggunakan uji hedonik, panelis memberikan penilaian dengan kode: 1) tidak suka dan 2) suka. Perhitungan uji hedonik dilakukan dengan cara menghitung ratarata pemilihan kode 1 dan 2 . Perbedaan daya terima diuji menggunakan uji Cochran's $Q$,, sedangkan untuk melihat formula yang berbeda menggunakan uji Mc Nemar dengan $\alpha=0,05$. Pengukuran kadar protein menggunakan perhitungan DKBM dan uji laboratorium dengan menggunakan analisis proksimat. Penelitian ini sudah di uji etik dengan nomor 546 - KEPK dari komisi etik penelitian Fakultas Kesehatan Masyarakat, Universitas Airlangga.

\section{HASIL DAN PEMBAHASAN}

Hasil penilaian oleh panelis terhadap tingkat kesukaan cilok menunjukkan bahwa penilaian tertinggi oleh panelis terdapat pada F0 $(1,76)$. Hasil penilaian oleh panelis terhadap tingkat kesukaan aroma cilok menunjukkan bahwa penilaian panelis tertinggi pada F0 $(1,69)$. Hasil penilaian oleh panelis terhadap tingkat kesukaan tekstur (kekenyalan) cilok menunjukkan bahwa penilaian panelis tertinggi pada F4 $(1,72)$. Hasil penilaian oleh panelis terhadap tingkat kesukaan rasa cilok 
Tabel 1. Perhitungan Formulasi Cilok Menggunakan DKBM

\begin{tabular}{|c|c|c|c|c|c|c|c|c|c|c|}
\hline \multirow{3}{*}{ Bahan } & \multicolumn{10}{|c|}{ Formulasi Cilok } \\
\hline & \multicolumn{2}{|c|}{ F0 } & \multicolumn{2}{|c|}{ F1 } & \multicolumn{2}{|c|}{ F2 } & \multicolumn{2}{|c|}{ F3 } & \multicolumn{2}{|c|}{ F4 } \\
\hline & $\begin{array}{c}\text { Berat } \\
\text { (g) }\end{array}$ & $\begin{array}{c}P \\
(g)\end{array}$ & $\begin{array}{c}\text { Berat } \\
\text { (g) }\end{array}$ & $\begin{array}{c}P \\
(g)\end{array}$ & $\begin{array}{c}\text { Berat } \\
\text { (g) }\end{array}$ & $\begin{array}{c}\mathbf{P} \\
(\mathrm{g})\end{array}$ & $\begin{array}{c}\text { Berat } \\
\text { (g) }\end{array}$ & $\begin{array}{c}\mathbf{P} \\
(\mathrm{g})\end{array}$ & $\begin{array}{c}\text { Berat } \\
\text { (g) }\end{array}$ & $\begin{array}{c}\text { P } \\
\text { (g) }\end{array}$ \\
\hline Tepung Kanji & 100 & 0,5 & 100 & 0,5 & 100 & 0,5 & 100 & 0,5 & 100 & 0,5 \\
\hline Tepung Terigu & 50 & 4,5 & 50 & 4,5 & 50 & 4,5 & 50 & 4,5 & 50 & 4,5 \\
\hline Daging Ikan Lele & 0 & 0 & 0 & 0 & 55 & 10,3 & 0 & 0 & 2 & 0,4 \\
\hline Isolated Soy Protein & 0 & 0 & 14 & 13,3 & 0 & 0 & 13 & 10,5 & 14 & 13,3 \\
\hline Tepung Badan Lele & 0 & 0 & 0 & 0 & 0 & 0 & 1 & 0,8 & 0 & 0 \\
\hline Tepung Kepala Lele & 0 & 0 & 0 & 0 & 0 & 0 & 2 & 0,6 & 0 & 0 \\
\hline Total & & 5,0 & & 18,3 & & 15,2 & & 16,8 & & 18,6 \\
\hline Total/100 gram & & 2,0 & & 6,6 & & 6,4 & & 6,3 & & 6,7 \\
\hline
\end{tabular}

Keterangan:

$\mathrm{P} \quad$ : protein

g : gram

F0 : tepung kanji, tepung terigu

F1 : tepung kanji, tepung terigu, ISP

F2 : tepung kanji, tepung terigu, daging ikan lele

F3 : tepung kanji, tepung terigu, tepung kepala lele, tepung badan lele

F4 : tepung kanji, tepung terigu, ISP, daging ikan lele

menunjukkan bahwa penilaian panelis tertinggi pada F0 $(1,62)$.

Penilaian panelis tertinggi berdasarkan hasil uji hedonik terhadap seluruh karakteristik cilok yang meliputi warna, aroma, tekstur (kekenyalan), dan rasa menunjukkan bahwa formula yang mendapat penilaian tertinggi adalah F0 $(1,69)$. Hasil uji Cochran's $Q$ pada daya terima siswa-siswi SD terhadap lima formulasi cilok menunjukkan bahwa terdapat perbedaan kesukaan panelis pada karakteristik warna dan rasa. Karakteristik cilok yang mempunyai perbedaan kesukaan yang bermakna, yaitu warna dan rasa akan diuji kembali dengan menggunakan uji statistik Mc Nemar.

Perbedaan yang bermakna terhadap warna cilok pada pasangan F0 dan F3 (cilok kontrol dan cilok dengan penambahan tepung ikan lele (Clarias gariepinus)), F1 dan F3 (cilok dengan penambahan ISP dan cilok dengan penambahan tepung ikan lele (Clarias gariepinus)), serta pasangan F2 dan F3 (cilok dengan penambahan daging ikan lele (Clarias gariepinus) dan cilok dengan penambahan tepung ikan lele (Clarias gariepinus)). Pada kategori rasa terdapat perbedaan yang bermakna terhadap rasa cilok pada pasangan F0 dan F3 (cilok kontrol dan cilok dengan penambahan tepung ikan lele (Clarias gariepinus)).
Tabel 2. Hasil Penilaian Uji Hedonik dan Uji Cochran's $Q$ terhadap Seluruh Karakteristik Cilok

\begin{tabular}{|c|c|c|c|c|c|}
\hline \multirow{2}{*}{ Formula } & \multicolumn{4}{|c|}{ Penilaian Cilok } & \multirow{2}{*}{$\bar{X}$} \\
\hline & Warna & Aroma & Tekstur & Rasa & \\
\hline F0 & 1,76 & 1,69 & 1,70 & 1,62 & 1,69 \\
\hline $\mathrm{F} 1$ & 1,65 & 1,49 & 1,56 & 1,52 & 1,56 \\
\hline $\mathrm{F} 2$ & 1,62 & 1,55 & 1,66 & 1,38 & 1,55 \\
\hline F3 & 1,46 & 1,54 & 1,59 & 1,55 & 1,53 \\
\hline F4 & 1,72 & 1,62 & 1,72 & 1,56 & 1,65 \\
\hline $\bar{X}$ & 1,64 & 1,58 & 1,65 & 1,52 & 1,60 \\
\hline p value & $0,002 *$ & 0,104 & 0,186 & $0,047^{*}$ & \\
\hline
\end{tabular}

*Keterangan: $\mathrm{p}$ value $<0,05$

Tabel 3. Hasil Uji Mc Nemar terhadap Daya Terima Warna dan Rasa

\begin{tabular}{ccc}
\hline \multirow{2}{*}{ Formulasi } & \multicolumn{2}{c}{ p value } \\
\cline { 2 - 3 } & Warna & Rasa \\
\hline F0 - F1 & 0,215 & 0,296 \\
F0 - F2 & 0,701 & 0,500 \\
F0 - F3 & $0,001^{*}$ & $0,006^{*}$ \\
F0 - F4 & 0,076 & 0,597 \\
F1 - F2 & 0,473 & 0,856 \\
F1 - F3 & $0,024^{*}$ & 0,121 \\
F1 - F4 & 0,871 & 0,690 \\
F2 - F3 & $0,003^{*}$ & 0,073 \\
F2 - F4 & 0,230 & 1,000 \\
F3 - F4 & 0,090 & 0,053 \\
\hline
\end{tabular}

Keterangan: * p value $<0,05$ 
Cilok dengan kandungan protein tertinggi menurut perhitungan Daftar Komposisi Bahan Makanan (DKBM) adalah F4 (cilok dengan penambahan Isolated Soy Protein 10\% dan daging ikan lele (Clarias gariepinus) 2\%) yaitu 6,70 gram/100 gram cilok. Hasil pengujian laboratorium menggunakan analisis proksimat terhadap formula F4 memberikan hasil yang lebih tinggi dari perhitungan DKBM dan angka kecukupan yang dianjurkan yaitu 9,40 gram/100 gram cilok. Salah satu alasan perbedaan nilai ini dikarenakan perhitungan DKBM dilakukan pada bahan mentah, sedangkan pengujian laboratorium dilakukan pada cilok yang sudah matang (Lestari, 2016).

Jajanan menyumbang 10\% hingga 15\% dari total kebutuhan protein sehari, angka tersebut jika dihitung dengan kebutuhan protein anak sekolah berdasarkan Angka Kecukupan Gizi (AKG) tahun 2013 adalah 4,9 gram hingga 8,4 gram (untuk anak laki-laki) dan 4,9 gram hingga 9,0 gram (untuk anak perempuan). Sehingga konsumsi cilok dari formula modifikasi yang dianjurkan agar memenuhi kecukupan protein adalah antara 7 hingga 13 biji cilok.

Hasil penelitian terhadap daya terima (warna, aroma, tekstur, dan rasa) berdasarkan uji hedonik pada cilok menunjukkan bahwa formula yang paling disukai oleh panelis yaitu F0, namun formula cilok F0 hanya menyumbang sedikit protein sehingga belum mencukupi angka kebutuhan protein yang dianjurkan untuk anak SD. Sedangkan F4 merupakan formula modifikasi yang memiliki kecukupan protein untuk jajanan anak SD namun daya terimanya masih kalah dengan formula F0 (kontrol). Panelis masih belum sepenuhnya menerima formula modifikasi dengan penambahan ikan lele dan Isolated Soy Protein (ISP) karena penggunaan bahan ini belum umum di pasaran

Hasil uji Cochran's $Q$ menunjukkan adanya perbedaan daya terima terhadap warna $(\mathrm{p}=0,002)$ dan rasa $(\mathrm{p}=0,047)$. Warna cilok modifikasi berbeda karena penambahan tepung ikan lele menyebabkan warna formula modifikasi menjadi lebih gelap. Sedangkan cilok yang diberi penambahan ikan lele (Clarias gariepinus) dan Isolated Soy Protein (ISP) tidak memberikan warna yang terlalu berbeda dengan formula kontrol.
Rasa cilok juga mengalami perbedaan daya terima karena panelis lebih terbiasa dengan rasa formula kontrol yang lebih umum di pasaran dan masih asing dengan penambahan ikan lele (Clarias gariepinus) dan Isolated Soy Protein (ISP) pada cilok. Konsumsi Isolated Soy Protein (ISP) sebagai bahan tambahan pada produk pangan, terutama pada cilok, masih cukup jarang. Konsumsi rata-rata protein kedelai di Jepang 8,7 g, Korea 6,2 hingga 9,6 g, Indonesia 7,4 g, dan Cina 3,4 g setiap hari (Barrett, 2006). Sedangkan di Amerika, 33\% orang yang mengonsumsi protein kedelai per bulannya (Michelfelder, 2009). Hal ini menunjukkan bahwa konsumsi protein kedelai masih rendah.

Setelah dilakukan uji statistik lanjut dengan Mc Nemar diketahui bahwa kesukaan terhadap warna cilok untuk formula yang dipasang dengan F kontrol (F0), didapatkan bahwa pasangan F0 dan F3 menunjukkan perbedaan secara nyata. Panelis kurang suka dengan warna cilok dengan konsentrasi tepung ikan lele (Clarias gariepinus) yang banyak. Formula cilok F3 memiliki warna agak gelap kecokelatan. Formula dengan penambahan tepung ikan lele memberikan warna yang lebih gelap karena warna dari tepung lele tersebut lebih gelap dibandingkan bahan lainnya.

Menurut penelitian Imandira (2012), semakin tinggi penambahan tepung ikan lele akan menghasilkan produk yang semakin coklat. Hal ini serupa dengan penelitian Apriana (2013) bahwa semakin besar konsentrasi tepung ikan lele maka warna yang dihasilkan pada cilok menjadi lebih coklat dibandingkan cilok dengan konsentrasi tepung ikan lele yang lebih rendah, menyebabkan warna asli cilok tidak menyerupai warna kontrolnya.

Penilaian terhadap rasa juga terdapat perbedaan antara F0 dengan F3. Hal ini sejalan dengan penelitian Apriana (2013) bahwa panelis cenderung kurang suka dengan rasa cilok dengan konsentrasi tepung ikan lele (Clarias gariepinus) yang banyak.

Berdasarkan tujuan awal dari pembuatan formulasi produk ini adalah agar dapat diterima oleh masyarakat terutama anak sekolah, namun tetap mempertimbangkan kecukupan protein. Meskipun formula F4 memiliki daya terima dibawah F0, namun komposisinya lebih beragam 
karena terdapat perpaduan daging ikan lele (Clarias gariepinus) dan Isolated Soy Protein (ISP) di dalamnya. Protein dari ikan lele saja belum cukup untuk memenuhi kecukupan protein dari cilok, maka dari itu digunakan Isolated Soy Protein (ISP) untuk membantu meningkatkan kecukupan protein karena protein yang terkandung pada ISP mencapai 90\% (Xiao, 2008).

\section{KESIMPULAN DAN SARAN}

Kesimpulan berdasarkan penelitian yaitu formula F4 memiliki kadar protein yang paling tinggi dibandingkan dengan formula lainnya. Namun daya terima formula F4 masih rendah sehingga disarankan untuk memodifikasi formula F4 dengan cara mengurangi ISP dan menambah daging ikan lele agar dapat meningkat daya terimanya.

\section{DAFTAR PUSTAKA}

Adriani, M., dan Wirjatmadi, B. (2012). Pengantar gizi masyarakat. Jakarta: Karisma Putra Utama.

Almatsier, S. (2011). Gizi seimbang dalam daur kehidupan. Jakarta: Gramedia Pustaka Utama.

Apriana, I. (2013). Pengaruh penambahan tepung kepala ikan lele (Clarias sp) dalam pembuatan cilok terhadap kadar protein dan nilai organoleptiknya. (Skripsi tidak diterbitkan). Universitas Negeri Semarang, Semarang.

Aprilia, B.A. (2011). Faktor yang berhubungan dengan pemilihan makanan jajanan pada anak sekolah dasar. (Skripsi tidak diterbitkan). Universitas Diponegoro, Semarang.

Andarwulan. (2009). Monitoring dan verifikasi profil keamanan pangan jajanan anak sekolah nasional tahun 2008. Bogor: Southeast Asian Food and Agricultural Science and Technology (SEAFAST).

Barrett, J.R. (2006). The science of soy: what do we really know?. Environmental Health Perpectives, 114(6), 352-358.

Hapsari, R.N. (2013). Kontribusi makanan jajanan terhadap tingkat kecukupan asupan energi dan protein pada anak sekolah yang mendapat PMT di SD Negeri Plalan 1 Kota Surakarta. Jurnal
Fakultas Ilmu Kesehatan, 1-12.

Hidayati, I.P. (2005). Hubungan antara pengetahuan dan sikap tentang gizi dengan praktik pemilihan makanan jajanan pada siswa di SD penyelenggara PMT-AS. (Skripsi tidak diterbitkan). Universitas Jenderal Soedirman, Purwokerto.

Imandira, P. (2012). Pengaruh substitusi tepung daging ikan lele (Clarias gariepinus) dan tepung ubi jalar kuning (Ipomoea batatas L.) terhadap kandungan zat gizi dan penerimaan biskuit balita tinggi protein. (Skripsi tidak diterbitkan). Universitas Diponegoro, Semarang.

Irianto. (2007). Panduan gizi lengkap keluarga dan olahragawan. Yogyakarta: Andi Offset.

Lestari, S. (2016). Pengaruh penambahan ikan lele (Clarias gariepinus) dan Isolated Soy Protein (ISP) pada cilok terhadap daya terima, nilai gizi dan nilai ekonomi. (Skripsi tidak diterbitkan). Universitas Airlangga, Surabaya.

Michelfelder, A.J. (2009). Soy: A complete source of protein. Am Fam Physician, 79(1), 43-47.

Mindell, E. (2008). Terapi kedelai bagi kesehatan. Jakarta: Delaprasta.

Montgomery, KS. (2003). Soy protein. The Journal of Perinatal Education, 12(3), 42-45.

Murphy, SP., Constance Gewa, C., Grillenberger, M., Bwibo, N.O., Neumann, C.G. (2007). Designing snacks to address micronutrient deficiencies in rural Kenyan school children. Jurnal of Nutrition, 137, 1093-1096.

Neumann, C.G., Bwibo, N.O., Murphy, S.P., Sigman, M., Whaley, S., Allen, L.H., Guthrie, D., Weiss, R.E., Demment, M.W. (2003). Animal source foods improve dietary quality, micronutrient status, growth and cognitive function in Kenyan school children: background, study design and baseline findings. $J$ Nutr, 133(11 Suppl 2), 3941S-3949S.

Suprapti, L. (2005). Tepung Tapioka Pembuatan dan Pemanfaatannya. Yogyakarta: Kanisius.

Syafitri, Y., Syarief, H., Baliwati, YF. (2009). Kebiasaan jajan siswa sekolah dasar (Studi Kasus di SDN Lawanggintung 01 Kota Bogor). Jurnal Gizi dan Pangan, 4(3), 167 - 175.

Xiao, C.W.(2008). Health effect of soy protein and isoflavones in humans. Journal of Nutrition, 138(6), 12445-12495. 